\title{
BLENDED LEARNING BERBASIS PLATFORM: STRATEGI PEMBELAJARAN EFEKTIF UNTUK PEMBELAJARAN MATEMATIKA PADA MASA PANDEMI COVID-19
}

\section{PLATFORM-BASED BLENDED LEARNING: EFFECTIVE LEARNING STRATEGIES FOR MATHEMATICS LEARNING DURING THE COVID-19 PANDEMIC}

\author{
Andi Kusumayanti \\ Fakultas Tarbiyah dan Keguruan Universitas Islam Negeri Alauddin Makassar \\ andi.kusumayanti@uin-alauddin.ac.id
}

\begin{abstract}
Abstrak
Pandemi Covid-19 menuntut para pendidik menerapkan pembelajaran dengan inovasi teknologi untuk mendukung pembelajaran jarak jauh yang efektif sebagai satu-satunya metode terbaik dari yang terburuk saat ini salah satunya adalah Blended learning berbasis platform. Tujuan dari penelitian ini adalah untuk mendeskripsikan konsep dan faktor pendukung pembelajaran Blended learning berbasis platform yang efektif pada masa pandemi covid-19 khususnya pada pembelajaran matematika. Jenis penelitian yang digunakan dalam penelitian ini adalah kepustakaan (library research). Dalam penelitian kepustakaan yang dilakukan ini data diperoleh dari berbagai buku-buku online, jurnal, majalah, dokumen, artikel online ataupun buku yang ada diperpustakaan yang berkaitan dengan strategi pembelajaran blended learning dan pembelajaran matematika pada masa pandemi covid-19. Instrumen pada penelitian kepustakaan ini adalah peneliti sendiri (human instrument). Adapun sumber datanya terdiri dari data primer dan sekunder. Selanjutnya, data-data baik primer maupun sekunder yang dikumpulkan diperoleh dengan cara membaca, mengkaji, memahami, dan mencatat literatur berkaitan dengan fokus penelitian ini. Teknik pengumpulan data dalam penelitian ini dilakukan dengan cara 1) mengumpulkan data-data berbasis pustaka artinya menggunakan buku-buku online, jurnal, majalah, dokumen, dan artikel online, 2) menganalisis sampai mendapatkan suatu kesimpulan. Teknik analisis data dalam penelitian kepustakaan ini terdiri dari analisis konten, deduktif, induktif, interpretatif, komparatif, dan historis. Hasil penelitian ini menyimpulkan bahwa blended learning sebagai strategi pembelajaran akan menjadi pembelajaran yang efektif atau tepat guna pada pembelajaran matematika jika didukung dengan platform yang tepat disertai instruksi-instruksi yang berbasis pembelajaran jarak jauh. Adapun komponen yang akan menjadi faktor penting yang dapat mendukung pembelajaran blended learning yang efektif selama pandemi covid-19 adalah a) jaringan yang stabil, b) literasi digital yang mumpuni mahasiswa maupun dosen, c) bahan ajar yang relevan dengan pembelajaran blended learning pada masa pandemi, d) perpaduan platform untuk mengatasi kendala-kendala yang mungkin terjadi dan menutupi setiap kelemahan yang dimiliki platform lainnya, e) rancangan proses belajar yang terstruktur.
\end{abstract}

Kata Kunci: blended learning, platform, pembelajaran matematika, pembelajaran efektif

\begin{abstract}
The Covid-19 pandemic requires educators to implement learning with technological innovation to support effective distance learning as the single best method of the worst today, one of which is platform-based Blended learning. The purpose of this study is to describe the concepts and factors supporting effective platform-based Blended learning during the covid-19 pandemic, especially in math learning. The type of research used in this study is literature (library research). In this literature research conducted data is obtained
\end{abstract}


from various online books, journals, magazines, documents, online articles or books that exist in the library related to blended learning strategies and mathematical learning during the covid-19 pandemic. The instrument in this literature research is the researcher himself (human instrument). The data source consists of primary and secondary data. Furthermore, both primary and secondary data collected are obtained by reading, reviewing, understanding, and recording the literature related to the focus of this research. The data collection technique in this study is done by 1) collecting library-based data means using online books, journals, magazines, documents, and online articles, 2) analyzing until you get a conclusion. Data analysis techniques in this literature research consist of content analysis, deductive, inductive, interpretive, comparative, and historical. The results of this study concluded that blended learning as a learning strategy will be an effective or appropriate learning in mathematics learning if supported by the right platform accompanied by instructions based on learning. The components that will be an important factor that can support effective blended learning during the covid-19 pandemic are a) a) stable networks, b) qualified digital literacy of students and lecturers, c) teaching materials relevant to blended learning in the pandemic period, d) the combination of platforms to overcome possible obstacles and cover every weakness that other platforms have, e) a structured learning process design.

Keywords: blended learning, platform, mathematics learning, effective learning

How to Cite: Kusumayanti, A. (2021). Blended learning berbasis platform: strategi pembelajaran efektif untuk pembelajaran matematika pada masa pandemi covid-19. Al asma: Journal of Islamic Education, 3(2), 263-274.

\section{PENDAHULUAN}

Matematika adalah ilmu yang abstrak, dan karena abstrak maka untuk memahaminya memerlukan daya abstraksi serta kemampuan yang memadai (Darhim, 2010). Oleh karena itu, tak heran jika matematika memang merupakan "kendaraan" utama untuk mengembangkan kemampuan berpikir logis dan keterampilan kognitif yang lebih tinggi pada anak-anak (Muijs \& Reynolds, 2008). Matematika sendiri memiliki andil yang penting dalam perkembangan bidang teknologi dan ilmu sains. Kenyataannya, belajar dan mengajar matematika bukanlah hal yang mudah. Sulitnya belajar matematika bagi sebagian besar perserta didik di Indonesia dapat dibuktikan dengan hasil penelitian survey yang dilakukan oleh PISA di tahun 2018 menempatkan Indonesia sebagai salah satu negara yang memiliki peserta didik dengan kemampuan matematika yang rendah. Berdasarkan hal tersebut, memang sepertinya matematika masih menjadi pelajaran yang tidak disukai oleh sebagian besar peserta didik. Keadaan ini menuntut para guru untuk terus menemukan solusi terbaik agar kondisi ini tidak terus berlajut. Jika dengan tatap muka secara langsung saja pembelajaran matematika sudah sulit lalau bagaimana dengan dengan kondisi pandemi covid-19 saat ini? Handayani \& Irawan (2020) mengatakan bahwa keadaan saat ini sudah jauh berbeda dari sebelumnya, dimana sebelumnya pembelajaran masih dilakukan secara manual tatap muka sekarang degan adanya wabah merubah segala aspek kehidupan tak terkecuali bidang Pendidikan. Kondisi ini justru semakin membuat pelajaran matematika semakin rumit untuk ajarkan dan dipelajari.

Pandemi Covid-19 menuntut para pendidik untuk menerapkan strategi-strategi berbasis platform-platform yang terkoneksi jaringan yang dapat mendukung pembelajaran jarak jauh. Tidak hanya bagi guru, peserta didikpun harus siap menghadapi 
kondisi ini. Karena dalam kondisi yang mendesak ini satu-satunya pembelajaran terbaik dari yang terburuk adalah pembelajaran jarak jauh dengan menggunakan platform yang terkoneksi dengan jaringan. Sehingga mau tidak mau, pembelajaran akan tetap berlangsung dalam kondisi apapun. Untuk mengatasi permasalahan tersebut, berbagai perusahaanpun meluncurkan platform digital dengan berbagai aplikasi belajar online dengan fitur-fitur yang memudahkan kegiatan belajar. Namun demikian, ketersediaan teknologi platform-platform sebagai media pembelajaran tentu tidak akan sempurna jika tidak digunakan dengan tepat dan tidak dipadukan dengan strategi pembelajaran. Oleh karena itu, sangat perlu menentukan strategi pembelajaran apa yang baik digunakan untuk mendukung pembelajaran jarak jauh. Salah satu strategi pembelajaran yang memadukan pembelajaran konvensional dengan ketersediaan teknologi adalah Blended learning. Blended learning atau pembelajaran campuran merupakan sebuah strategi pembelajaran yang bertujuan untuk mencapai tujuan pembelajaran dengan cara memadukan pembelajaran berbasis tatap muka dengan pembelajarn berbasis teknologi informasi yang dilakukan secara daring (Widiara, 2018). Blended learning memungkinkan terjadinya refleksi terhadap pembelajaran (Wibawa, 2018). Blended learning merupakan satu-satunya strategi pembelajaran yang tepat digunakan pada masa pandemi. Tetapi apakah pelaksanaannya sudah efektif? Kenyataannya, berdasarkan hasil observasi dilapangan penggunaan strategi pembelajaran dengan memanfaatkan platform sebagai media pembelajaran justru tidak mendukung secara maksimal pembelajaran matematika yang dianggap sulit bagi sebagian besar peserta didik. Hal ini juga dijelaskan dalam penelitian yang dilakukan oleh Lubis (2020) yang menjelaskan bahwa kurang efektifnya pembelajaran jarak jauh karena faktor kurangnya sarana dan prasarana serta ketidaksiapan edukasi teknologi. Penelitian tersebut menegaskan ada yang perlu diperbaharui dalam pembelajaran jarak jauh karena pembelajaran daring tidak berjalan maksimal karena jaringan yang buruk (Kusumaningrum \& Wijayanto, 2020). Oleh karena itu, berdasarkan temuan tersebut sangat perlu mengkaji bagaimana sebaiknya pembelajaran matematika dengan strategi blended learning berbasis platform yang efektif.

\section{METODE PENELITIAN}

Jenis penelitian yang digunakan dalam penelitian ini adalah kepustakaan (library research). Dalam penelitian kepustakaan yang dilakukan ini data diperoleh dari berbagai buku-buku online sebanyak 3, jurnal tentang pembelajaran jarak jauh sebanyak 10, majalah, dokumen tentang pembelajaran jarak jauh sebanyak 5, artikel online ataupun buku yang ada diperpustakaan yang berkaitan dengan strategi pembelajaran blended learning sebanyak 5 dan pembelajaran matematika pada masa pandemi covid-19. Zed (2008) mengatakan bahwa dalam dalam penelitian kepustakaan terdapat empat langkah yang harus dilaksanakan dalam rangka mengkaji teori diantaranya adalah 1) menyiapkan alat perlengkapan, 2) menyusun bibliografi kerja, 3) mengatur waktu, 4) membaca dan membuat catatan penelitian. Instrumen pada penelitian kepustakaan ini adalah peneliti sendiri (human instrument). Adapun sumber datanya terdiri dari data primer dan sekunder. Selanjutnya, data-data baik primer maupun sekunder yang dikumpulkan diperoleh dengan cara membaca, mengkaji, memahami, dan mencatat literatur berkaitan dengan fokus penelitian ini. Teknik pengumpulan data dalam penelitian ini dilakukan dengan cara 1) mengumpulkan data-data berbasis pustaka artinya menggunakan buku- 
buku online, jurnal, majalah, dokumen, dan artikel online, 2) menganalisis sampai mendapatkan suatu kesimpulan. Teknik analisis data dalam penelitian kepustakaan ini terdiri dari analisis konten, deduktif, induktif, interpretatif, komparatif, dan historis. Deduktif adalah pemikiran yang bertolak pada fakta-fakta yang umum kemudian ditarik pada suatu kesimpulan yang bersifat khusus. Induktif adalah mengambil suatu konklusi atau kesimpulan dari situasi yang kongkrit menuju pada hal-hal yang abstrak, atau dari pengertian yang khusus menuju pengertian yang bersifat umum. Interpretatif adalah menginterpretasikan suatu makna ke dalam makna normatif. Komparatif adalah membandingkan objek penelitian dengan konsep pembanding. Historis adalah melakukan analisis kejadian-kejadian dimasa yang lalu untuk mengetahui kenapa dan bagaimana suatu peristiwa itu telah terjadi.

\section{HASIL DAN PEMBAHASAN}

\section{Pembelajaran Matematika pada Masa Pandemi}

Pembelajaran matematika adalah suatu kegiatan belajar ilmu pengetahuan menggunakan nalar dan memiliki rencana terstruktur dengan melibatkan pikiran serta aktifitas dalam mengembangkan kemampuan pemecahan masalah dan menyampaikan suatu informasi atau gagasan (Wandini, 2019). Aktivitas pembelajaran matematika adalah suatu proses pemberian pengalaman belajar kepada peserta didik melalui serangkaian kegiatan yang terencana sehingga peserta didik memperoleh pengetahuan mengenai materi yang dipelajari (Patimah, Lyesmaya, \& Maula, 2020). Pembelajaran matematika merupakan serangkaian kegiatan yang dilakukan oleh guru, dosen, pelatih menggunakan media ataupun sumber belajar dalam satu ruang kelas untuk membantu perserta didik yang diajarnya memahami atau terampil matematika. Hal ini bertujuan agar belajar matematika siswa terarah sesuai dengan hierarki matematika dan mengetahui apa saja yang dibutuhkan siswa ketika belajar matematika untuk meningkatkan pemahamannya. Untuk mendukung perolehan hasil belajar matematika siswa yang maksimal maka dalam pelaksanaan proses belajar matematika maka seluruh komponen pendukung harus saling terkait dan menunjang.

Menurut Solichin (2006) prinsip belajar matematika ada tiga. 1) perhatian dan motivasi sebagai pendorong aktivitas belajar peserta didik, 2) keaktifan sebagai sikap positif dan daya penggerak peserta didik untuk berinisiatif melakukan aktivitas belajar, 3) perlu terlibat langsung dan berpengalaman supaya anak dapat membangun pengetahuannya sendiri melalui aktifitas yang ada. Selain itu, dalam pembelajaran matematika siswa dituntut untuk melakukan kegiatan mental yang relatif tinggi (Karso, 2014). Sebab itu peserta didik harus senantiasa berpartisipasi aktif dalam pembelajaran. Jika hal ini tidak dilakukan maka akan sulit rasanya seorang guru membantu siswanya belajar matematika karena dalam pembelajaran matematika ada yang berkenaan dengan ide abstrak serta penggunaan simbol yang disusun secara hierarkis dan penalaran yang deduktif sehingga siswa perlu mendapatkan bimbingan yang maksimal pula dalam proses belajarnya. Namun demikian, untuk memaksimalkan pembelajaran pada kondisi pandemi covid-19 saat ini bukanlah hal yang mudah. Pandemi covid-19 menyebabkan proses pembelajaran konvensional (tatap muka) dihentikan sementara waktu (Niani \& Rahma, 2020). 
Perubahan rangkaian kegiatan belajar mengajar yang dilakukan secara mendadak karena kehadiran virus COVID-19 ini membuat semua elemen pendidikan yang terlibat maupun orangtua merasakan dampak perubahan yang terjadi. Dampak proses pembelajaran yang harus dilaksanakan dari rumah mewajibkan pendidik memanfaatkan teknologi yang terkoneksi jaringan sebagai media pembelajaran. Berbagai kendala yang dihadapi dalam pelaksanaan pembelajaran matematika secara daring sebaiknya dijadikan tantangan bagi guru untuk meningkatkan pendidikan yang berbasis teknologi. Apalagi dengan pembelajaran matematika yang pada dasarnya sudah dianggap sulit oleh sebagian besar siswa, ditambah lagi jika tidak tidak langsung diajarkan dengan tatap muka atau pembelajaran konvensional. Beberapa kendala dalam pelaksanaan Blended learning antara lain kemampuan SDM baik guru/dosen maupun siswa/mahasiswa (Rachmah, 2019). Namun, pembelajaran berbasis teknologi seperti saat ini setidaknya memberi kesempatan dan peluang bagi pendidik agar dapat meningkatkan dan mengembangkan kompetensinya khususnya kompetensi pedagogik dan professional (Ardiansyah \& Sulistyaningsih, 2020). Pemanfaatan media pembelajaran berbasis platform yang terkoneksi jaringan atau aplikasi yang berbasis multimedia dapat dijadikan sebagai alternatif dalam membimbing peserta didik untuk memahami materi pelajaran dengan baik.

Selain itu, kreativitas guru menyajikan pembelajaran matematika yang menyenangkan dan interaktif sangat penting pada kondisi covid-19 saat ini. Hal ini bertujuan agar siswa tetap dapat berpartisipasi aktif meskipun pembelajaran dilakukan dari rumah. Selanjutnya, ketika membuat rancangan proses pembelajaran, guru sebaiknya mempertimbangkan materi atau topik apa saja yang kemungkinan di anggap sulit oleh siswa yang akan diajarnya. Setiap pertimbangan harus dipastikan bahwa tidak hanya siswa yang memliki kemampuan yang tinggi yang menganggap sulit tetapi siswa dengan kemampuan yang sedang dan rendah juga menjadi target dalam mencapai tujuan pembelajaran. Oleh karena itu, guru harus terus berupaya memilih cara yang sesuai dengan kemampuan siswanya agar mereka memahami materi dengan baik. Selain penyajian materi, pemilihan media dan strategi pembelajaran juga perlu dipertimbangkan dan disesuaikan dengan kebutuhan siswa, karekteristik siswa, dan materi yang akan diajarkan apakah sesuai dengan media yang akan digunakan. Adapun strategi pembelajaran yang tepat digunakan pada masa pandemi covid-19 saat ini adalah blended learning. Oleh karena itu, sangat penting memahami konsep pembelajaran blended learning.

\section{Konsep Pembelajaran Blended learning}

Blended learning merupakan merupakan inovasi pemanfaatan teknologi informasi dalam dunia pendidikan. Ada dua unsur utama dalam pembelajaran blended learning, yakni pembelajaran di kelas dengan tatap muka secara konvensional (classroom lesson) dengan pembelajaran secara online (Mosa, 2006). Blended learning adalah suatu model yang menggabungkan pembelajaran tatap muka dengan pembelajaran berbasis teknologi yang dapat diakses online dan offline (Saputra \& Priskawati, 2020). Menurut Semler dalam (Husamah, 2014) blended learning memberikan kemudahan pembelajaran karena dapat dipadukan dengan berbagai teknik penyampaian, model, sumber belajar baik media maupun bahan ajar yang mendukung pelaksanaan pembelajaran antara siswa dan pendidik. Bentuknya dapat beragam mulai dari penggunaan komputer dalam menunjang 
pembelajaran sampai dengan komplemen pembelajaran tatap muka dengan E-learning. Strategi pembelajaran dapat dijelaskan berdasarkan gambar 1 berikut.

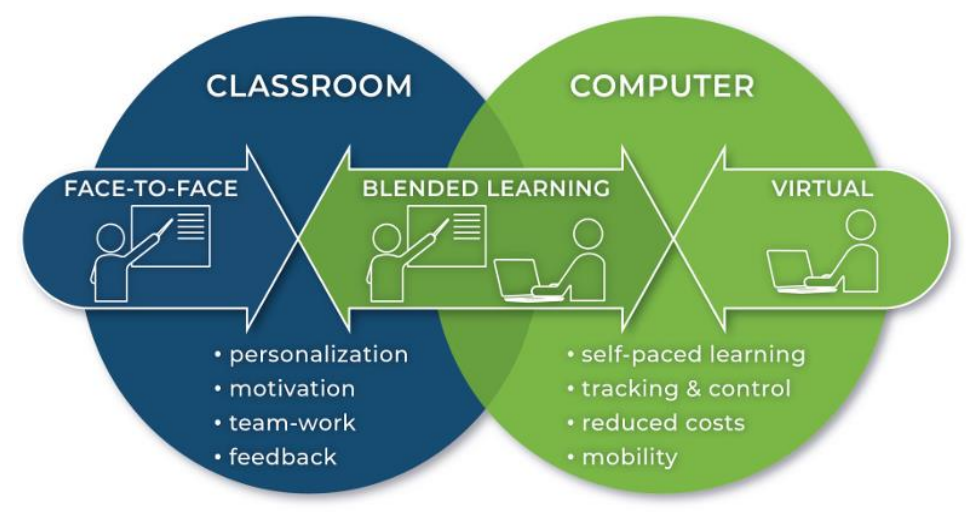

Gambar 1. High Quality Blended Learning (Centrul Tehnologic Educational, 2020)

Pada gambar 1, dapat diketahui bahwa blended learning merupakan integrasi dari kelas tatap muka dengan kelas virtual dimana kelas tatap muka mencakup personalisasi, motivasi, kerja tim, umpan balik, sedangkan kelas virtual mencakup pembelajaran mandiri, pelacakan \& kontrol, pengurangan biaya, mobilitas Berdasarkan beberapa pendapat tersebut maka dapat disimpulkan bahwa strategi pembelajaran blended learning adalah perpaduan dua unsur pembelajaran yaitu pembelajaran berbasis teknologi secara online dan tatap muka secara konvensional.

Maathoba (2017) menjelaskan bahwa karakteristik umum strategi pembelajaran blended learning terdiri dari empat diantaranya adalah 1) pembelajaran yang menggabungkan berbagai model, gaya belajar, penyampaian, serta media ajar yang berbasis teknologi yang bervariasi, 2) pembelajaran dengan mengkombinasikan pembelajaran face to face, belajar mandiri dan belajar mandiri via online, 3) pembelajaran yang didukung dengan kombinasi efektif dari cara penyampaian, cara mengajar dan gaya belajar yang diterapkan, 4) guru dan orangtua bersama-sama mendorong siswa dalam belajar, guru sebagai fasilitator di sekolah dan orangtua sebagai pendukung di rumah. Sementara itu, Lalima dan Dangwal (2017) mengatakan bahwa terdapat 13 karakter utama dalam strategi pembelajaran blended learning 7 diantaranya adalah 1) siswa memiliki dua pilihan metode pembelajaran, 2) guru berpengalaman dengan dua metode pilihan tersebut, 3) siswa dapat berinteraksi langsung ataupun secara virtual, 4) siswa mendapatkan pengalaman penuh dalam menggunakan teknologi baru, 5) siswa mendapatkan pelatihan dalam keterampilan hidup yang berbeda, 6) dapat meningkatkan literasi digital siswa, 7) pembelajaran yang berpusat pada siswa, 8) guru memiliki peran yang beragam

Husamah (2014) mengatakan bahwa jika blended learning ini dilaksanakan dengan maksimal, maka salah satu manfaat yang dapat diperoleh adalah dapat meningkatkan hasil pembelajaran melalui pendidikan jarak jauh dan meningkatkan kemudahan belajar sehingga siswa menjadi puas dalam belajar. Blended learning mempunyai potensi untuk memecahkan metode pembelajaran cara lama dan membuat 1) penyesuaian pembelajaran pembelajaran akan menyesuaikan dengan data peserta didik, umpan balik secara tepat waktu dan jadwal yang fleksibel, 2) pembelajaran berbasis kompetensi peserta didik 
dianggap berhasil jika sudah menguasai materi bukan berdasarkan waktu belajar, 3) pembelajaran dimana saja dan kapan saja (Arsenault, 2019). Penerapan blended learning bukanlah hal yang mudah terdapat beberapa syarat-syarat dasar dalam pelaksanaan blended learning diantaranya adalah (Lalima \& Dangwal, 2017) 1) Dosen/guru yang terlatih dengan baik, 2) Mempunyai sikap ilmiah , 3) Mempunyai sikap dan sudut pandang yang luas serta bersikap positif terhadap perubahan, 4) Fasilitas lengkap seperti laboratorium komputer, 5) Peserta didik mempunyai akses internet, 6 Fleksibilitas dalam sistem, 7) Orang tua sadar dan setuju dengan blended learning, 9) Evaluasi dilakukan secara berkelanjutan dan fleksibel.

Pradnyana (2013) menyebutkan tujuan dari pembelajaran blended learning adalah 1) membantu peserta didik untuk berkembang lebih baik di dalam proses belajar, sesuai dengan gaya belajar dan preferensi dalam belajar, 2) menyediakan peluang yang praktis realistis bagi pendidik dan peserta didik untuk pembelajaran secara mandiri, bermanfaat, dan terus berkembang, 3) peningkatan penjadwalan fleksibilitas bagi peserta didik, dengan menggabungkan aspek terbaik dari tatap muka dan instruksi online, 4) kelas tatap muka dapat digunakan untuk melibatkan para peserta didik dalam pengalaman interaktif. sedangkan porsi online memberikan peserta didik dengan konten multimedia yang kaya akan pengetahuan pada setiap saat, dan di mana saja selama peserta didik memiliki akses internet, 5) mengatasi masalah pembelajaran yang membutuhkan penyelesaian melalui penggunaan metode pembelajaran yang bervariasi.

Menurut Damanik (2019) strategi pembelajaran blended learning memiliki kelebihan antara lain 1) peserta didik dapat leluasa mempelajari materi pelajaran secara mandiri dengan memanfaatkan materi materi yang tersedia secara online, 2) peserta didik dapat berkomunikasi bahkan berdiskusi dengan guru atau peserta didik lain yang tidak harus dilakukan saat di kelas, 3) guru dapat menambahkan materi pengayaan melalui media online, dapat meminta peserta didik membaca materi atau mengerjakan tes yang dilakukan sebelum pembelajaran, memberikan kuis, dan memanfaatkan hasil tes dengan efektif, 4) mengurangi aktivitas bermain-main siswa dengan cara mengisi hal-hal bermanfaat yang dapat dilakukannya dengan gadgetnya yakni mengerjakan tugas secara online.

Selain memiliki kelebihan juga terdapat beberapa kelemahan (Damanik, 2019) antara lain 1) proses pembelajaran yang hanya memanfaatkan teknologi saja tidak dapat sepenuhnya berhasil. Hal tersebut dikarenakan gaya belajar masing-masing siswa berbeda-beda, 2) guru tidak dapat mengontrol kegiatan siswa di luar tatap muka secara penuh, 3) hasil pengerjaan tugas memungkinkan siswa satu dengan yang lain saling berbagi, 4) siswa yang cenderung mempunyai minat belajar yang rendah kesulitan belajar secara mandiri dengan pembelajaran online ini, 5) tingkat akses yang baik tidak semua siswa memiliki.

\section{Komponen pendukung terlaksananya Blended learning berbasis platform yang efektif}

Kehadiran strategi pembelajaran blended learning sebagai solusi pembelajaran pada masa pandemi memudahkan setiap pelaku pendidikan karena dapat digunakan kapan dan dimanapun dan tanpa batas waktu. Siswa dapat mengakses sumber belajar yang tersedia yang sudah dikemas secara terstruktur untuk mendukung belajar mandiri siswa. Proses tanya jawab yang mudah tanpa harus dibatasi dengan jam pelajaran sehingga interaksi yang terjadi tidak terbatas di ruang kelas saja. Sementara itu, peran 
guru dalam pembelajaran berbasis blended learning sangat penting dalam mengelola pembelajaran. Di samping keharusan memiliki keterampilan mengajar dalam menyampaikan isi pembelajaran secara tatap muka, guru juga sebaiknya memiliki pengetahuan dan keterampilan dalam mengembangkan sumber belajar berbasis platform yang terkoneksi oleh jaringan dan keterampilan untuk mengakses internet. Hal ini karena pada masa pandemi saat ini pembelajaran matematika yang dilaksanakan dalam jaringan merupakan suatu keharusan yang harus dijalani karena tidak ada pilihan lain selain pembelajaran dalam jaringan. Bukan hanya sekedar mengimplementasikan, guru dituntut untuk menemukan pembelajaran matematika secara online yang efektif pada masa pandemic. covid-19 saat ini. Oleh karena itu, sangat penting menelaah pembelajaran matematika yang efektif. Berikut ini adalah faktor-faktor penting yang dapat mendukung pembelajaran daring yang efektif selama pandemi covid-19 yang di rangkum dari berbagai hasil penelitian.

a. Jaringan yang stabil

Setelah beberapa bulan menjalankan pembelajaran berbasis daring, banyak hasil penelitian yang menjelaskan bahwa salah satu penyebab tidak berjalannya secara maksimal pembelajaran daring jaringan yang tidak stabil. Hal ini dapat dibuktikan beberapa hasil penelitian yang mengatakan bahwa koneksi jaringan internet yang tidak stabil membuat pembelajaran menjadi tidak maksimal (Anugrahana, 2020; Rigianti, 2020). Meskipun telah banyak penelitian yang menjelaskan bahwa koneksi jaringan yang tidak stabil menjadi kendala dalam pembelajaran daring ataupun blended learning, sampai hari ini masih belum ada solusi untuk mengatasi permasalahan tersebut. Oleh karena itu, faktor ini masih menjadi PR bagi pemerintah dalam mewujudkan pembelajaran daring dimasa pandemi yang efektif dengan ketersediaan kondisi jaringan yang baik.

b. Literasi digital yang mumpuni mahasiswa maupun dosen

Literasi digital merupakan aspek terpenting pada sector Pendidikan saat ini. Perkembangan koneksi jaringan yang masif di bidang pendidikan dimasa pandemi ini berdampak positif terhadap kehidupan masyarakat yang dapat selalu terhubung. Hal ini sejalan dengan Brian (dalam (Maulana, 2015) yang mengatakan bahwa salah satu manfaat literasi digital saat ini adalah kehidupan akan selalu terhubung dalam dunia maya. Salah satunya dengan pembelajaran, pembelajaran yang dilakukan dengan media pembelajaran yang terkoneksi dengan jaringan membuat proses belajar menjadi tidak terbatas antara jarak dan waktu. Ilmu pengetahuan dapat diperoleh dengan cepat serta sumber belajar yang luas dan banyak. Hal ini sejalan dengan pendapat Sumiati dan Wijonarko (2020) yang mengatakan bahwa dalam literasi digital seseorang yang ingin menemukan informasi dapat dilakukan dengan cepat hanya dengan menggunakan media elektronik seperti komputer dan smartphone. Kenyataannya dengan kondisi yang awalnya penuh tantangan bagi guru karena tidak semua guru dan siswa memiliki kemampuan literasi digital yang mumpuni berangsur-angsur semakin mampu beradaptasi dan menguasai keterampilan tersebut karena hampir setiap hari mereka gunakan karena tuntutan.

c. Bahan ajar yang relevan dengan pembelajaran blended learning pada masa pandemi

Pada pelaksanaannya, blended learning dimasa pandemi sudah tentu perlu didukung dengan bahan ajar yang relevan. Relevan dalam artian bahwa bahan ajar yang dibuat guru sebaiknya dikemas dalam bentuk yang menarik, dapat memotivasi siswa 
untuk belajar mandiri, dan user friendly. Apalagi pembelajaran blended learning dimasa pandemi saat ini lebih banyak mengharapkan siswa belajar secara mandiri maka siswa harus dibekali dengan bahan ajar yang memudahkan mereka untuk memahami pelajaran (Jasmi, 2020). Oleh karena itu, guru harus dapat memilih bahan ajar yang sesuai dengan kurikulum yang digunakan dan yang paling penting adalah sesuai dengan kebutuhan siswa untuk mencapai tujuan pembelajaran. Dalam mengembangkan bahan ajar ada beberapa kompetensi yang harus diperhatikan diantaranya adalah harus materi pembelajaran, informasi pendukung, petunjuk penggunaan, instruksi, latihan - latihan, dan evaluasi, rangkuman

d. Perpaduan platform untuk mengatasi kendala-kendala yang mungkin terjadi dan menutupi setiap kelemahan yang dimiliki platform lainnya

Setelah beberapa bulan melaksanakan pembelajaran daring, kenyataannya tidak semua platform yang berbasis jaringan dapat memenuhi kebutuhan belajar siswa yang efektif. Setiap platform pasti memiliki kekurangan dan kelebihan. Oleh karena itu, untuk menutupi setiap kelemahan suatu platform maka perlu dipadukan dengan platform lainnya. Wiryanto (2020) mengatakan bahwa guru dan siswa di dalam pembelajaran daring dapat memanfaatkan berbagai macam platform dengan aplikasi seperti google meet, google classroom, zoom video, whatsapp, google drive, google form dan lain-lain

e. Rancangan proses belajar yang terstruktur

Strategi pembelajaran kombinasi ini dirasa cukup efektif dalam memberikan materi pembelajaran matematika, memang tidak dapat dipungkiri ini menjadi belum maksimal seperti biasanya pembelajaran matematika yang disajikan secara luring (Kencawaty, Febriyanti, \& Irawan, 2020). Oleh karena itu, implementasi blended learning tidak dapat dilaksanakan begitu saja. Dalam menerapkan blended learning guru perlu melakukan pertimbangan yang matang khususnya yang berkaitan dengan tujuan pembelajaran yang ingin kita capai. Arsenault (2019) mengatakan bahwa terdapat beberapa petunjuk yang dapat digunakan untuk mengembangkan bleded learning yang efektif diantaranya adalah 1) identifikasi masalah dan tujuan yang akan dicapai, 2) membangun tim blended learning, 3) memotivasi peserta didik, 4) meningkatkan pembelajaran, 5) memilih teknologi, 6) mendesain kelas, 7) memilih model blended learning, 8) membuat budaya baru, 9) blended learning adalah proses.

\section{SIMPULAN}

Berdasarkan beberapa hasil studi pustaka yang telah dilakukan dapat disimpulkan bahwa pembelajaran blended learning adalah kegiatan pembelajaran yang memadukan strategi pembelajaran dan media pembelajaran (teknologi) dalam mencapai tujuan pembelajaran. Proses belajar yang bisa dilaksanakan dimana pun dan kapanpun dapat mendukung proses belajar mandiri mahasiswa dan relevan untuk berbagai karakteristik yang dimiliki siswa pada saat ini. Blended learning merupakan solusi pembelajaran pada masa pandemi covid-19 saat ini. Tidak ada pembelajaran lain yang dapat dilakukan selain dengan pembelajaran dalam jaringan. Hal ini juga menjadi kelebihan dari model ini. Adapun kekurangannya adalah pembelajaran ini membutuhkan keterampilan yang baik dalam menerapkannya sehingga tidak semua guru secara cepat bisa menggunakannya. Oleh karena itu, guru dalam waktu yang cepat dan singkat dituntut untuk dapat menemukan model, media, sumber ataupun bahan ajar mana yang sesuai digunakan untuk 
siswa yang akan diajarnya. Sementara itu, faktor-faktor penting yang dapat mendukung pembelajaran blended learning yang efektif selama pandemi covid-19 yang di rangkum dari berbagai hasil penelitian diantaranya adalah a) jaringan yang stabil, b) literasi digital yang mumpuni mahasiswa maupun dosen, c) bahan ajar yang relevan dengan pembelajaran blended learning pada masa pandemic, d) perpaduan platform untuk mengatasi kendala-kendala yang mungkin terjadi dan menutupi setiap kelemahan yang dimiliki platform lainnya, e) rancangan proses belajar yang terstruktur. Hasil kajian ini diharapkan bisa menjadi referensi bagi para pengajar dalam menerapkan blended learning dimasa pandemic covid-19 saat ini. Selain itu, penelitian ini juga bisa menjadi acuan bagi peneliti lainnya yang tertarik dengan pembelajaran di masa pandemic covid-19.

\section{DAFTAR PUSTAKA}

Anugrahana, A. (2020). Hambatan, solusi dan harapan: pembelajaran daring selama masa pandemi covid-19 oleh guru sekolah dasar. Scholaria: Jurnal Pendidikan Dan Kebudayaan, 10(3), 282-289.

Ardiansyah, E. S. N., \& Sulistyaningsih, D. (2020). Analisis proses pembelajaran matematika berbasis daring menggunakan aplikasi microsoft teams materi persamaan logaritma pada masa pandemi covid - 19. Prosiding Seminar Edusaintek, 4(1), 22-28.

Arsenault, A. (2019). Why blended learning? clayton christensen institute. Clayton Christensen Institute. https://www.christenseninstitute.org/blended-learning/

Centrul Tehnologic Educational. (2020). Time for high quality blended learning, but why? MIT Center.

Damanik, R. N. (2019). Daya tarik pembelajaran berbasis blended learning di era revolusi 4.0. Prosiding Seminar Nasional Fakultas Ilmu Sosial Universitas Negeri Medan.

Darhim. (2010). Teori belajar matematika (Bahan PLPG).

Handayani, S. D., \& Irawan, A. (2020). Pembelajaran matematika di masa pandemic covid19 berdasarkan pendekatan matematika realistic. Jurnal Math Educator Nusantara, 6(2), 179-189. https://doi.org/10.29407/jmen.v6i2.14813

Husamah. (2014). Pembelajaran bauran (blended learning). Prestasi Pustakarya.

Jasmi, O. (2020). Upaya peningkatan kompetensi guru menulis hand out melalui in house training di masa pandemi. Inovasi Pendidikan, 7(2), 102-112. https://jurnal.umsb.ac.id/index.php/inovasipendidikan/article/view/2308

Karso, H. (2014). Pembelajaran matematika di sd [Universitas Terbuka]. http://repository.ut.ac.id/4026/

Kencawaty, G., Febriyanti, C., \& Irawan, I. (2020). Tantangan dan strategi pembelajaran matematika di masa adaptasi kebiasaan baru (akb) dampak dari covid-19. Prosiding Seminar Nasional Dan Diskusi Panel Pendidikan Matematika Universitas Indraprasta PGRI. http://proceeding.unindra.ac.id/index.php/DPNPMunindra/article/view/4740

Kusumaningrum, B., \& Wijayanto, Z. (2020). Apakah pembelajaran matematika secara daring efektif? (studi kasus pada pembelajaran selama masa pandemi covid-19). KREANO: Jurnal Matematika Kreatif-Inovatif, 11(2), 136-142. https://journal.unnes.ac.id/nju/index.php/kreano/article/view/25029 
Lalima, \& Dangwal, K. L. (2017). Blended learning: an innovative approach. Universal Journal of Educational Research, 5(1), 129-136. http://www.hrpub.org/journals/article_info.php?aid=5495

Lubis, W. (2020). Analisis efektivitas belajar pada pembelajaran jarak jauh (pjj) di masa pandemi covid-19. Jurnal Bahastra (Bahasa Dan Sastra Indonesia), 5(1), 132-141. https://jurnal.uisu.ac.id/index.php/Bahastra/article/view/3282/2242

Maathoba, A. (2017). Blended learning. ACADEMIA. https://www.academia.edu/38308657/Blended_Learning_By_Aman_Maathoba_

Maulana, M. (2015). Definisi, manfaat dan elemen penting literasi digital. ACADEMIA. https://www.academia.edu/21277105/Definisi_Manfaat_dan_Elemen_Penting_Lit erasi_Digital

Mosa, E. (2006). A blended e-learning model. Italian Journal Of.

Muijs, D., \& Reynolds, D. (2008). Effective teaching: teori dan aplikasi edisi kedua. Pusaka Pelajar.

Niani, C. R., \& Rahma, C. (2020). Analisis kendala sistem belajar daring terhadap pembelajaran matematika di kampus. Math Educa Journal Jurnal Matematika Dan Pendidikan Matematika, 4(2), 114-122. https://ejournal.uinib.ac.id/jurnal/index.php/matheduca/article/view/1730

Patimah, S., Lyesmaya, D., \& Maula, L. H. (2020). Analisis aktivitas pembelajaran matematika pada materi pecahan campuran berbasis daring (melalui aplikasi whatsapp) di masa pandemi covid-19 pada siswa kelas 4 sdn pakujajar cbm. JKPD (Jurnal Kajian Pendidikan Dasar), 5(2), 98-105. https://doi.org/https://doi.org/10.26618/jkpd.v5i2.3679

Pradnyana, G. A. (2013). Blended learning.

Rachmah, H. (2019). Blended learning: memudahkan atau menyulitkan? [Universitas Negeri Medan]. http://digilib.unimed.ac.id/39395/

Rigianti, H. A. (2020). Kendala pembelajaran daring guru sekolah dasar di kabupaten banjarnegara. Elementary School, 7(2), 297-302.

Saputra, J., \& Priskawati, D. (2020). Blended learning: solusi pembelajaran new normal untuk pendidikan agama kristen di era revolusi industri 4.0. Jurnal Pendidikan DIDAXEI, 1(2), 104-113.

Solichin, M. M. (2006). Belajar dan mengajar dalam pandangan al-ghazali. Tadris: Jurnal $\begin{array}{lll}\text { Pendidikan Islam, 1(2), 138-153. } & \end{array}$ http://ejournal.iainmadura.ac.id/index.php/tadris/article/view/202

Sumiati, E., \& Wijonarko. (2020). Manfaat literasi digital bagi masyarakat dan sektor pendidikan pada saat pandemi covid-19. Buletin Perpustakaan Universitas Islam Indonesia, 3(2), 65-80. https://journal.uii.ac.id/BuletinPerpustakaan/article/view/17799

Wandini, R. R. (2019). Pembelajaran matematika untuk calon guru mi/sd. CV Widya Pustaka.

Wibawa, S. (2018). Pendidikan dalam era revolusi industri 4.0. Indonesia. UST.

Widiara, I. K. (2018). Blended Learning Sebagai Alternatif Pembelajaran Era Digital. Purwadita : Jurnal Agama Dan Budaya, 2(2). 
Wiryanto. (2020). Proses pembelajaran matematika di sekolah dasar di tengah pandemi covid-19. Jurnal Review Pendidikan Dasar, 6(2), 1-8. https://doi.org/https://doi.org/10.26740/jrpd.v6n2.p125-132

Zed, M. (2008). Metode penelitian kepustakaan. Yayasan Obor Indonesia. 